\title{
After Neoliberalism: A Social Structure of Accumulation or Mode of Regulation for Global or Regional Performance?
}

\author{
Phillip Anthony O’Hara*
}

\author{
philohara@yahoo.com
}

[Final JEI Version, Double Spaced] [V6c]

\begin{abstract}
This paper examines the extent to which neoliberal or post-neoliberal forces have been generating a new global or regional social structure of accumulation (SSA) or mode of regulation (MOR) through enhancing growth, productivity and financial stability. After outlining the contours of neoliberalism and post-neoliberalism, the record of economic performance is reviewed over the 1950s-2000s. Highly advanced capitalist economies have mostly been undergoing regime maturation while numerous nations of Asia (especially China) have been transforming their social structure of accumulation or mode of regulation. Neoliberal and postneoliberal forms of governance are only part of the institutional apparatus affecting economic performance. They must necessarily be supplemented by some minimal combination of (a) (especially) dynamic systems of production and distribution, as well as (b) stable and effective finance, (c) some moderation of competition, (d) integrative global institutions, and (e) suitable institutions of community and family, to enhance economic performance.
\end{abstract}

Keywords: neoliberalism, post-neoliberalism, social structure of accumulation, mode of regulation

JEI Classification Codes: B52, D24, E02, N10, G01

Neoliberalism has been undergoing emergence, transformation and evolution over the past thirty years around the world, especially since the time of Thatcherism and Reaganomics in the late 1970s and 1980s. It emerged in response to the presume failure of the previous Keynesian policy of using discretionary fiscal and monetary policy, industry incentives and big government to solve some of the core public goods problems of the age. The

\footnotetext{
* The author is Professor of Global Political Economy \& Governance, and Director of the Global Political Economy Research Unit (GPERU) in the Curtin Business School, Curtin University, Perth, Australia. The paper was prepared for presentation at the annual meetings of the Association for Evolutionary Economics in Atlanta, January 2010. Email: philohara1@yahoo.com
} 
question is raised in this paper as to what the record of socioeconomic performance has been under neoliberal governance and whether there is in motion a movement towards a post-neoliberal social structure of accumulation (SSA) or mode of regulation (MOR).

The question of a new and effective SSA or MOR concerns whether there is in place a suitable set of production-distribution systems and institutions to promote sustainable long-term growth, productivity and stability. Usually MOR scholars place emphasis on global or regional developments, while SSA scholars concentrate on national progress. On the basis of David Kotz's (1994) idea that there is much to be gained by linking both traditions, some authors have started also to analyze SSAs in the world economy and MORs in national economies (O’Hara 2006a). This paper merges the two traditions while recognizing the need to give priority to the regime of accumulation (productivity and demand).

A MOR is a production-distribution system (regime of accumulation) which generates sustained productivity and effective demand to stimulate GDP growth for (usually) several decades; plus a set of ancillary institutions to facilitate stability, cooperation and governance (Aglietta 1979). The global or regional Fordist MOR, for instance, during the 1950s-1970s was based around a system of assembly line production, economies of scale, Keynesian-welfare state, a moderation of competition, and consumer demand with relatively high wages. The relative demise of Fordism through the 1970s and 1980s led to the question of what might replace it, and how this may evolve into the future. The flexible system of production, for instance, was proposed as a possible alternative, based on economies of scope, multi-skilling, total quality management and just-in-time inventory systems. Some fusion of Fordist technology and the flexible system set within the global economy is another possibility. The regulation approach then situates various institutions as possibly accommodating the generation of a new regime, such as neoliberalism or the post-neoliberal system, along with a series of institutional clusters associated with finance and global arrangements.

The SSA approach is somewhat different as it situates a number of institutional clusters as potentially promoting a macro or global SSA. The postwar corporate system (Bowles, Gordon and Weisskopf 1990), in the United States, for instance, was based (during the 1950s-1970s) around a dynamic system of productiondistribution (the capital-labor accord), US hegemony in the world economy, a balance between monopoly and competition, the capital-state accord (Keynesian-welfare state), regulated finance (Wolfson 1994) and a viable community and family system (O’Hara 1995). Many other advanced capitalist economies developed similar institutional clusters, though often with differences. Into the mid-1970s the contradictions within this postwar corporate system began to manifest through declining productivity, low growth and considerable financial inistability. In response to the perceived failures of traditional Keynesian policy, Thatcherism and Reaganomics, along with supply side, rational choice and Washington Consensus philosophies led to the 
dominance of neoliberalism in many nations into the 1980s and 1990s.

This paper centres on whether neoliberalism has been promoting the creation of a new, viable regime of accumulation (in the MOR) or production-distribution institutions (in the SSA), characterized by high rates of GDP growth, sustainably high rates of productivity and financial stability (O’Hara 2006). We also explore whether state institutional clusters are to some degree going beyond neoliberalism, and whether these forces might be stimulating a new and vibrant regime of production or production-distribution system. These MOR and SSA regulation approaches are a core element of institutional-evolutionary political economy, as has been documented in the Journal of Economic Issues, for instance, by Stanfield (1984) and O’Hara (1994).

\section{Neoliberal and Post-Neoliberal Governance}

Four dominant trends associated with neoliberal state institutions have been operating in many nations and international institutions over the past 30 years (see O’Hara 2000, 2006b for details). First, there is a belief in small government. The neoliberal consensus posits the need to reduce the size of government to a far smaller percentage of GDP than was typical in the postwar era (1950s-early 1970s). It seeks to privatize government enterprises, reduce red tape, and increase corporate self-governance. Secondly, the wave of neoliberal policies enacted from the late-1970s to the 1990s attempted to deregulate the domestic financial system through a series of institutional changes. Controls over interest rates and on the separation of wholesale from retail banking, for instance, were dismantled. This was based on the belief that controls hurt those who can least gain access to finance by reducing the overall availability of finance.

The third plank of neoliberalism has been to deregulate the labor market through reforming industrial relations. The main objective of these policies was to reestablish the power, profitability and viability of individual corporations so as to increase growth and accumulation. The fourth plank of neoliberalism is to free up international capital so that the global circuit of business can expand. This was done by promoting the free movement of money, production and trade worldwide.

Since the late 1970s and 1980s, neoliberal principles were imposed not only in many of the advanced capitalist nations, but also on several nations in Africa, South and Central America and to some degree Central and Eastern Europe. The pattern of neoliberal control has not been uniform, and more recently (especially) challenges to this control have emerged. For instance, China and many emerging Asian nations used industry policy and state-corporate networks to enhance development. Scandinavia never did abandon their belief in the mixed economy. The threat of AIDS saw the need for the state to actively intervene in the social economy, especially in Africa. The Asian financial crisis and the corporate crises of the late-1990s and early 2000s emerged in an environment of financial deregulation, which has since seen a backlash against neoliberal 
policies. Latin America has reacted against crises, problematic performance and other problems by electing a whole series of so-called socialist and social democratic governments through the late-1990s and 2000s. More latterly, the global subprime crisis has seen diminishing legitimacy for neoliberal policies, although this may take some time to be reflected in official data. These post-neoliberal policies tend to include productive public capital for education, health, communications and infrastructure; discretionary fiscal and monetary policies; institutions for community governance; and expanding the concerns of industry (and the environment) over finance.

\section{Global and Regional Performance}

Here we examine the global and regional performance of economies in the light of these governance trends throughout the world. Table 1, below, scrutinizes the long-term rate of growth of GDP per capita.

Table 1. Growth of Real GDP Per Capita in the Global Economy

\begin{tabular}{|l|l|l|l|l|l|l|l|}
\hline $\begin{array}{l}\text { Maddison } \\
\text { Data } \downarrow \rightarrow\end{array}$ & World & $\begin{array}{l}\text { Advanced } \\
\text { Capitalist } \\
\text { Nations }\end{array}$ & $\begin{array}{l}\text { Latin } \\
\text { America \& } \\
\text { Caribbean }\end{array}$ & MENA & Africa & $\begin{array}{l}\text { Eastern } \\
\text { Europe }\end{array}$ & $\begin{array}{l}\text { Asia } \\
\text { (Excl. } \\
\text { Japan) }\end{array}$ \\
\hline $1950-1973$ & 2.93 & 3.72 & 2.52 & n.a. & 2.07 & 3.49 & 2.92 \\
\hline $1973-2001$ & 1.43 & $1.98^{*}$ & 1.08 & n.a. & 0.38 & $-1.10^{*}$ & $3.54^{*}$ \\
\hline \hline $\begin{array}{l}\text { World Bank } \\
\text { Data } \downarrow \rightarrow\end{array}$ & & $\begin{array}{l}\text { High- } \\
\text { Income } \\
\text { OECD }\end{array}$ & & & $\begin{array}{l}\text { Sub- } \\
\text { Saharan } \\
\text { Africa }\end{array}$ & & $\begin{array}{l}\text { East Asia } \\
\text { \& Pacific }\end{array}$ \\
\hline $1970-79$ & 2.11 & 2.90 & 3.22 & 3.44 & 1.22 & n.a. & 5.02 \\
\hline $1980-89$ & 1.28 & 2.35 & -0.28 & -0.60 & -0.75 & 1.60 & 5.99 \\
\hline $1990-99$ & 1.22 & 1.77 & 1.25 & 1.98 & -0.69 & $-2.26^{*}$ & 6.81 \\
\hline $2000-08$ & 1.34 & 1.55 & 2.34 & 2.53 & 2.26 & $\begin{array}{l}7.56 \ddagger[C I S-11] \\
{[2000-2007]}\end{array}$ & 7.83 \\
\hline
\end{tabular}

Source: Adapted from: Maddison (2000: 126, 129); World Bank (2009). $\quad$ † is from UNECE (2009)

$\dagger 2009$ is an estimate (IMF 2009) * 1973-2000 or 1990-2000. a. = not available.

These figures show that the high world growth rates in the "golden age" of the 1950s through to the early1970s were not re-established during the "neoliberal era” (as Maddison 2001 calls it) of the mid-late 1970s onwards through the 1980s, 1990s (and 2000s). Growth performance has not significantly improved for the world as a whole, and certainty not for the nations of the advanced Western world which were most tenacious in advancing the neoliberal agenda (e.g., USA, UK, and Australia).

The growth performance of Latin America, the Middle East, Africa and Eastern Europe has been mixed. Like the advanced capitalist nations, virtually all these (sub)continents went through much higher growth rates in the 1950s-1970s than the 1970s-1990s. However their performance into the 1980s and 1990s, when the neoliberal influence was strongest, were generally well below par. It was only during the 2000s that growth started to make a moderate comeback. The late 1990s and 2000s was a time when numerous socialist governments were elected in Latin America to stem the tide of financial instability and unproductive 
investment. Islamic influences became stronger in the Middle East and North Africa into the 2000s as the War against terrorism and fundamentalist Islam expanded. Eastern European performance collapsed during the 1990s, while the recovery into the 2000s is in part due to a counter-movement to the earlier collapse. SubSaharan African economies have begun to make a modest comeback into the 2000s as eclectic, responsible governance is taking hold in some economies such as Botswana, South Africa, Angola and Mozambique.

However, it is clear that more is happening around the world than merely neoliberalism and the double movement against the free market through post-neoliberal governance. By itself, neither neoliberal nor postneoliberal forms of governance could reverse the trend of mediocre performance exhibited by many areas, nor be the focus of high growth rates of China and other nations of especially Asia. A key tenet of SSA and MOR approaches is that institutional and technological advances need to occur in other spheres-besides policy and governance-before performance can be majorly affected. For instance, Table 2, below, provides an outline of the key changes usually sought for long wave upswing in performance (see O’Hara 2003):

Table 2. Core SSA and MOA Systems Affecting Performance

\begin{tabular}{|c|c|c|c|c|c|c|c|}
\hline & Cluster 1 & Cluster 2 & Cluster 3 & Cluster 4 & Cluster 5 & Cluster 6 & Cluster 7 \\
\hline SSAs & $\begin{array}{l}\text { Production- } \\
\text { Distribution }\end{array}$ & $\begin{array}{l}\text { Moderation } \\
\text { of } \\
\text { Competition }\end{array}$ & $\begin{array}{l}\text { World } \\
\text { Economy } \\
\text { Institutions } \\
\end{array}$ & $\begin{array}{l}\text { Financial } \\
\text { System }\end{array}$ & $\begin{array}{l}\text { Policy and } \\
\text { Governance }\end{array}$ & $\begin{array}{l}\text { Family and } \\
\text { Community }\end{array}$ & $\begin{array}{l}\text { Environmental } \\
\text { Technologies } \\
\text { and Systems }\end{array}$ \\
\hline MOA & $\begin{array}{l}\text { ROA: } \\
\text { Technology } \\
\text { Style }\end{array}$ & $\begin{array}{l}\text { ROA: } \\
\text { Regulation } \\
\text { of } \\
\text { Consumption }\end{array}$ & $\begin{array}{l}\text { Institutional } \\
\text { Form 1: } \\
\text { Finance }\end{array}$ & $\begin{array}{l}\text { Institutional } \\
\text { Form 2: } \\
\text { Policy }\end{array}$ & $\begin{array}{l}\text { Institutional } \\
\text { Form 3: } \\
\text { Global } \\
\text { Relations } \\
\end{array}$ & $\begin{array}{l}\text { Institutional } \\
\text { Form 4: } \\
\text { Environmental } \\
\text { Systems }\end{array}$ & \\
\hline
\end{tabular}

This table illustrates some of the changes likely to be necessary for a new sustainable increase in socioeconomic performance in both the SSA and MOA approaches. The SSA approaches tend to place emphasis on the need for the development of several institutional clusters (seven shown above) to stimulate long-term growth, productivity and stability. Of these seven, special note should be given to the institutional clusters of "policy and governance” and the likely need for future institutions and styles of "environmental technologies and systems”; but these are no more important than the other five clusters, such as the systems of production and distribution. Similarly, MOA approaches give priority to an effective regime of accumulation, constituting both a technology style enhancing productivity and a system of consumption to stimulate longterm effective demand. The institutions beyond these realms are considered important but secondary; e.g., finance, competition, policy, etc. In both approaches policy and governance are linked with the other systems, but mentioned as clusters simply in order to show them as being relatively autonomous.

The clearest trend is the inability of advanced capitalist economies to undergo a new regime of production or social structure of accumulation, irrespective of their governance tendencies. Of course, 
neoliberalism has been an important part of the movement in many of these advanced nations to construct a new and viable regime of long-term growth and productivity. But there are many other institutions and production systems at stake than just free markets and less government.

Take a look at the GDP performance of numerous high-income OECD economies, in Table 3, below:

\section{Table 3. GDP Growth Per Capita Performance of High-Income OECD Nations}

\begin{tabular}{|l|l|l|l|l|l|l|l|}
\hline & Sweden & Norway & Finland & S/N & US & UK & Australia \\
\hline $1960-69$ & 3.35 & 3.24 & 3.94 & 1.27 & 2.97 & 2.02 & 3.29 \\
\hline $1970-79$ & 2.04 & 3.85 & 3.67 & 1.54 & 2.23 & 2.26 & 1.70 \\
\hline $1980-89$ & 2.02 & 2.41 & 3.12 & 1.23 & 2.11 & 2.22 & 1.80 \\
\hline $1990-99$ & 1.28 & 3.03 & 1.15 & 0.94 & 1.87 & 1.86 & 2.10 \\
\hline $2000-08$ & 2.19 & 1.74 & 2.77 & 1.26 & 1.39 & 2.02 & 1.91 \\
\hline
\end{tabular}

Source: Adapted from World Bank (2009)

This comparison of GDP per capita growth rates between the Scandinavian and more neoliberal economies reveals two main things. Firstly, Scandinavian (S) growth rates have mostly been significantly above those nations of a more neoliberal $(\mathrm{N})$ persuasion $[\mathrm{S} / \mathrm{N}]$. And secondly, the growth rates of both groups of nations have been unevenly declining since the 1960s (or 1970s). Some other factors are at play besides policy and governance processes. Indeed, it is the regulation approach that gives a privileged position to the regime of accumulation determining productivity and demand. Long wave upswing, therefore, is said to depend primarily on the development of a viable and proactive technology-production system and a mode of regulation of consumption. In both groups of nations such a regime is nowhere forthcoming.

A similar story is told with the aid of productivity figures, in Table 3 below. Here the advanced nations of the OECD have been experiencing increasingly lower rates of productivity growth since the 1960s and 1970s, including both explicitly neoliberal economies and also Scandinavian economies. The rates of growth during the 2000s are especially low, into single digits. On the other hand, the relatively highly developed and emerging economies of Asia have experienced much more rapid growth than any other areas in recent decades. The examples of China and South Korea are compared in Table 4, below, with neoliberal and Scandinavian economies:

Table 4 Labor Productivity Growth, 1960-2008 (GDP per Hour Worked) (annual average rate of change) (GDP, Output, per work hour)

\begin{tabular}{|l|l|l|l|l|l|l|l|l|}
\hline & China & Korea* & Finland & Sweden & Norway* & USA* & UK$^{*}$ & Australia* \\
\hline $1960-1970$ & n.a. & n.a. & n.a. & n.a. & n.a. & 3.7 & 4.3 & $\begin{array}{l}2.73 \\
{[1964-74]}\end{array}$ \\
\hline $1971-1979$ & 2.60 & & 3.67 & 1.68 & 4.60 & 2.0 & 2.5 & 1.59 \\
\hline $1980-1989$ & 3.18 & 6.09 & 2.95 & 1.16 & 2.30 & 1.8 & 5.7 & 1.24 \\
\hline $1990-1999$ & 7.30 & 5.43 & 2.74 & 1.94 & 2.72 & 2.0 & 2.2 & 2.41 \\
\hline $2000-2008^{*}$ & $\begin{array}{l}13.30 \\
{[2000-04]}\end{array}$ & 4.19 & 1.93 & 1.93 & 1.37 & 2.03 & 2.06 & 1.11 \\
\hline
\end{tabular}

Source: * = OECD (2009). Non-* data is adapted from US Department of Labor (2000: 95, 101; 2001). Non-* data is for the manufacturing sector; and non-* U.S. data is for the business sector as a whole. Chinese data is adapted from Holz (2006:25). Australian data for 1964-74 is from PC (2007). Data for the 2000s is for the private sector as a whole. 
What this data for GDP and productivity growth tells us is that the highly developed capitalist economies have been experiencing a structural decline in their ability to generate a technology style and productivity regime (production and distribution institutions) to support accumulation and growth. When the old-style Fordist system declined into the 1970s and 1980s no viable regime of accumulation emerged to take its place. The rapidly growing and developing economies of Asia, on the other hand, have been experiencing a long wave upswing characterized by a regime of accumulation that exhibits high growth, productivity and real wage benefits.

As to the nature of the accumulation regime characterized by the rapidly emerging nations of Asia, it comprises (a) export orientation, (b) state industry policy support, (c) balance between industry and finance, and (d) the movement of labor from rural to urban and city centers (O’Hara 2006c). In China, for instance, the movement of population comprises around 10 million per year from the underemployed regions of the countryside to the new industrial towns and cities of the East and South-East. This exploitation of new labor is accompanied by high rates of labor productivity, lesser rates of capital productivity, and higher real wages. Clearly, non-neoliberal state and governance processes impact of this system through laws, regulations, enablers, and networks, and to this extent they are closely integrated into the systems of production and distribution.

No comparable regime of accumulation exists in the other areas of the world, including the advanced capitalist economies of the EU, North America, Japan and Australia. These nations have mostly exhausted the movement of population from the rural areas, also mostly women have moved from the household into the labor market. The main potential supply of labor comes from immigration. However, there is no viable mode of regulation of consumption in these nations, such as happened in the era of Fordism when the working class mode of consumption was high, credit moderate, providing a good basis for demand along with the Keynesianwelfare state. Currently in most advanced capitalist nations of the West and Japan, consumption is enhanced by debt (rather than wages), which has not helped the building of a sustainable regime of accumulation, while large current account deficits are common.

\section{Financial Instability and the Mode of Consumption}

One area where neoliberalism has been having a major impact has been through deregulation of the financial system; reducing the power of labor compared to capital; and increasing the role of credit in production and consumption. All major areas of the world have been influenced by this trend, even to some major degree Scandinavia, Japan and Germany. Indeed, even the highly developed and emerging Asian nations deregulated their financial systems to some major degree in the 1970s and 1980s, which played a role in the Asian crisis of 
the late 1990s.

Deregulating financial markets and reducing the power of labor versus capital are linked to changes in corporate governance over several decades. In the 1950s, 1960s and 1970s the core emphasis for large corporations was growth through expansion and investment. Accumulation and profit rates were relatively high and this led to high rates of growth, as did the higher wages that added demand to consumption expenditures. But the neoliberal trend, especially in advanced capitalist nations, of deregulating finance and labor markets led to less demand for industry and productive investment and more for finance and consumption goods. This shift from productive to relatively unproductive (fictitious capital) spending played a role in the declining productivity and growth rates of the 19780s, 1990s and 2000s.

This has been well documented by the research of Binswanger (2000), Stockhammer 2004), Palley (2007), O’Hara (2009) and others who show that financialisation is a core tendency of advanced capitalist nations while industry has been in remission. Placing emphasis on shareholder value, the equity market and debt has increased systemic risk and the tendency for financial crises to recur and become more intense. For instance, Table 5, below, shows the trend towards more extreme financial crises from the great boom of the 1949s-1970s to the downgrade of the 1970s-1990s.

Table 5. Banking, Currency Crises in the World: 1945-1997: 21 Nation Sample

\begin{tabular}{|l|l|l|l|l|l|l|}
\hline & $\begin{array}{l}\text { Probability of } \\
\text { Crisis (\% } \\
\text { point chance) }\end{array}$ & $\begin{array}{l}\text { Number } \\
\text { of Currency } \\
\text { Crises only }\end{array}$ & $\begin{array}{l}\text { Number } \\
\text { of Banking } \\
\text { Crises only }\end{array}$ & $\begin{array}{l}\text { Twin } \\
\text { crises only }\end{array}$ & $\begin{array}{l}\text { Output Loss } \\
\text { of Crises } \\
\text { (\% points of } \\
\text { growth lost) }\end{array}$ & $\begin{array}{l}\text { Recovery } \\
\text { Time (years } \\
\text { for output to } \\
\text { normalize) }\end{array}$ \\
\hline $1945-1971$ & 7.04 & 37 & 1 & 1 & 5.24 & 1.78 \\
\hline $1973-1997$ & 9.68 & 86 & 26 & 27 & 7.77 & 2.64 \\
\hline
\end{tabular}

Source: Adapted from Eichengreen \& Bordo (2002)

Comparing the upswing of 1945-1971 with the downswing of 1973-1997, banking and currency crises increased markedly. Financial crises became more pronounced in the 1980s than the 1970s, and more pronounced in the 1990s than the 1980s. There was only 1 banking crisis during the long-wave upswing of 1945-1971, but 26 during the downswing of the 1970s-1990s. There were 37 currency crises during the upswing, but 86 during downswing. Overall, the probability, number, output loss, and recovery time associated with crises were all much greater during the time of neoliberalism than beforehand. The real problem is the emergence of twin crises (currency and banking crises), which were only 1 in number during long wave upswing, but 27 during the downswing when neoliberalism was strong (O’Hara 2006b).

Recently also the world has been experiencing the greatest global crisis and recession since the Great Depression of the 1930s. While full data will not emerge until well into 2010 or 2011, Table 6 compares the impact of financial crises over historical time, including the subprime crises of 2007-2009: 
Table 6. International Financial Crises and Recessions, Impact, 1889-2009

\begin{tabular}{|c|c|c|c|c|c|}
\hline & Title of Crisis & $\begin{array}{l}\text { Severity of } \\
\text { Crisis }\end{array}$ & $\begin{array}{l}\text { Global } \\
\text { Depression } \\
\text { or Recession }\end{array}$ & $\begin{array}{l}\text { Global } \\
\text { GDP } \\
\text { Growth }\end{array}$ & $\begin{array}{l}\text { Number } \\
\text { Crises/Nations } \\
\text { Involved }\end{array}$ \\
\hline 1889-92 & Baring Crisis & Significant & n.a. & n.a. & n.a. \\
\hline $1929-32$ & Great Depression & Catastrophic & $\begin{array}{l}-35 \% \\
(1930-32) \\
\end{array}$ & n.a. & Whole World \\
\hline $1974-75$ & $1^{\text {st }}$ Postwar Crises & $\begin{array}{l}\text { Moderately } \\
\text { Severe }\end{array}$ & $\begin{array}{l}-1.39 \% \\
(1974-75)\end{array}$ & $\begin{array}{l}\text { 1970-79: } \\
2.11 \%\end{array}$ & $\begin{array}{l}\text { 1970s: } 7 \text { crises } \\
\text { Some core areas }\end{array}$ \\
\hline $1980-88$ & $\begin{array}{l}\text { Global Recession } \quad \& \\
\text { Debt Crises }\end{array}$ & Severe & $\begin{array}{l}-1.42 \% \\
(1982)\end{array}$ & $\begin{array}{l}\text { 1980-89: } \\
1.28 \%\end{array}$ & $\begin{array}{l}\text { 1980s: } 33 \text { crises } \\
\text { Much of World incl. Latin } \\
\text { America, SSA }\end{array}$ \\
\hline $\begin{array}{l}1990-92, \\
1997-99\end{array}$ & $\begin{array}{l}\text { Global Recession, plus } \\
\text { Russian \& Asian Crises }\end{array}$ & Severe & $\begin{array}{l}-0.02 \% \\
(1991)\end{array}$ & $\begin{array}{l}\text { 1990-99: } \\
1.22 \%\end{array}$ & $\begin{array}{l}\text { 1990s: } 58 \text { crises } \\
\text { Much of World incl. } \\
\text { Russia, Asia }\end{array}$ \\
\hline $\begin{array}{l}\text { 2001-03, } \\
\text { 2007-09 }\end{array}$ & $\begin{array}{l}\text { Internet \& Subprime } \\
\text { Crises \& Recessions }\end{array}$ & $\begin{array}{l}\text { Very Severe } \\
(2007-09)\end{array}$ & $\begin{array}{l}-2.5 \% \quad(2009) \\
\text { (Estimate) }\end{array}$ & $\begin{array}{l}\text { 200-09: } \\
1.34 \%\end{array}$ & $\begin{array}{l}\text { 2000s: } 85 \text { crises for } 2009 . \\
\text { Most Nations (esp. } \\
\text { advanced) }\end{array}$ \\
\hline
\end{tabular}

Source: Adapted from various sources; including World Bank (2009); IMF (2009:128-9); O’Hara (2009). For number of crises/nations involved for the 1970s-1990s, see Herro \& Rio (2003:53). ${ }^{\dagger}$

This data shows that there have been several international financial crises, including none during long wave upswing of the 1950s-early 1970s, and several during the long wave downswing in the advanced nations and elsewhere during the 1970s-2000s. The 1970s saw seven major financial crises; and this grew to 33 crises in the 1980s, 58 crises in the 1990s, and then to 85 crises during the time of the subprime crisis. Financial instability has thus majorly increased over the decades as shareholder value, fictitious capitals, unproductive state spending and high debt levels have increased instability. The subprime crisis, for instance, is the greatest global crisis and recession since the Great Depression of the 1930s. It brought home not merely problems of neoliberalism and deregulation of finance, but also anomalies of finance often having a greater financial return than industry due to an insufficiently developed regime of accumulation.

The evidence is clear that the trend to financialization is closely linked with the trend to neoliberalism; but it also goes beyond simply neoliberalism. It relates to the changing motivation of corporations from growth to shareholder value, and to the sectoral metamorphosis from industry to services. The advanced capitalist economies (in particular) have been undergoing industrial maturation and hegemonic decline, while much of Asia is experiencing a systemic rise in power. Thus we are seeing major changes in core, periphery and semiperiphery relationships at the global, regional and local levels. History has always experienced these periods of

\footnotetext{
† The method for calculating the number of nations involved in the global subprime crises impacts (2007-09) is to calculate the number of nations undergoing negative real GDP growth (not per capita) during the whole of 2009 (based on estimates from IMF (2009:170, 171-176)). This is a viable method since, for 2007-09, the financial crisis caused the recession, rather than the other way around which is usually the case (O’Hara 2009a).
} 
uneven development, while currently we are seeing a major shift in power from the centre to the semiperiphery.

In the meantime, it is likely that the core nations will continue to experience a high degree of financial instability, low growth and perhaps deep recession which can often impact negatively on peripheral and semiperipheral nations. When finance dominates industry and the service sector is the most rapidly growth sector, productivity changes are likely to be below par in the advanced nations. While this certainly represents a continuing period of long wave downswing (at least for the advanced capitalist areas), the question does arise as to whether any forces are at work generating new industries and potential long wave upswing. Sectoral metamorphoses are long-term in nature, and no movement is currently at work generating major productivity increases into the future for the advanced Western nations. Instead we are likely to see advances in Asia and possibly other continents in the periphery and semi-periphery.

But what of the policy changes that are happening on the back of the subprime crisis and recession? These include more proactive fiscal and monetary policy, highly activist lender of last resort, a deepening of deposit insurance, nationalizations of core financial institutions, as well as greater transparency, more prudential functions, and recognizing the importance of systemic risk. More generally these changes indicate that even in a framework of late-neoliberal maturity and likely demise some considerable flexibility and adaptability exists in governance which is a healthy sign, preventing major depression for the world. Will these policy changes result in a decline in neoliberalism and the emergence of a new social structure of accumulation or mode of regulation? While these changes auger in a new period of declining power and significance for neoliberalism in favor of more balanced forms of governance, many more changes are likely needed for long wave upswing. The prime change, as indicated above, is for a new and dynamic mode of regulation, including a regime of accumulation generating both productivity increases and effective demand expansions. Industrial changes and the current state of capital-labor relations does not proffer well in this respect, at least in the advanced capitalist nations. Many more systemic and core institutional changes are required before long wave upswing is likely to emerge.

\section{Conclusion}

This paper raised the question of whether neoliberalism has had some positive influence on socioeconomic performance by affecting social structures of accumulation or modes of regulation. It also raised the issue of whether there have been any changes beyond neoliberalism that may auger in a post-neoliberal framework, and whether this may be affecting performance and institutional potentiality. The conclusions made are that neoliberalism hasn't improved performance, if anything quite the contrary; and that some post-neoliberal 
changes may be positively affecting some nations and areas.

However, the paper emphasizes that a new social structure of accumulation or regime of accumulation depends on a much wider sphere of changes than simply the terrain of neoliberal versus post-neoliberal governance. New SSAs and regimes depend on policy, but also capital-labor relations, competition-monopoly linkages, family-community processes, finance, trade, and most importantly production and distribution arrangements. Examined within this wider framework, the world as a whole has not established a (series of) dynamic system(s) of production and distribution for long wave upswing. However, China and the Asian archipelago have been undergoing a remarkable industrial transformation which represents a viable social structure of accumulation and mode of regulation. Some of the other continents, such as Latin America, SubSaharan Africa, the Middle East and Eastern Europe have made some improvements, but not enough for long wave upswing at this stage.

Neoliberalism is thus only one aspect of the institutional and technological environment necessary to transform the political economies of the world. The wider question is the need for a new viable regime of accumulation to promote productivity and effective demand. The major capitalist economies are mostly undergoing industrial metamorphosis where industry is dominated by finance, where productivity and GDP growth per capita are insufficient to auger in a new long wave upswing. Even if post-neoliberal institutions emerge victorious out of the current global subprime crisis, many more systemic changes are needed for sustainable growth and development into the future, for the advanced nations and many others.

\section{References}

Aglietta, Michel. A Theory of Capitalist Regulation: The US Experience. London: Verso Books, 1979. (Translated from the French.)

Binswanger, Mathias. “Stock Returns and Real Activity: Is There Still a Connection?,” Applied Financial Economic 10 (2000): 379-387.

Bowles, Sam, David Gordon and Thomas Weisskopf. After the Wasteland: A Democratic Economic for the Year 2000, Armonk, NY \& London: M.E.Sharpe, 1990.

Eichengreen, Barry \& Michael D. Bordo. Crises Number Now and Then: What Lessons from the Last Era of Financial Globalization? New York: National Bureau of Economic Research: Working Paper 8716, 2002. Herrero, Alicia Garcia. Financial Stability and the Design of Monetary Policy. Servicio De Estudios. Documento de Trabajo Number. 0315. Madrid: Banco de Espana, 2003.

IMF (International Monetary Fund.) World Economic Outlook. October 2009.

Kotz, David M. “The Regulation Theory and the Social Structure of Accumulation.” In Social Structures of 
Accumulation: The Political Economy of Growth and Crisis, edited by David M. Kotz, Terrence McDonough and Michael Reich, pp. 83-97. Cambridge: Cambridge University Press.

Maddison, Angus. The World Economy: A Millennial Perspective. Paris: OECD, 2001.

OECD. “Productivity Data: Numerous Nations”, Statistics Portal. Paris: OECD, 2009. Online.

O’Hara, Phillip Anthony. “An Institutionalist Review of Long Wave Theories: Schumpeterian Innovation, Modes of Regulation, and Social Structures of Accumulation.” Journal of Economic Issues 28 (1994): 489500.

O’Hara, Phillip Anthony. "Household Labor, the Family, and Macroeconomic Instability in the United States: 1940s-1990s”, Review of Social Economy 53 (1995): 89-120,

O’Hara, Phillip Anthony. "The Evolution of a New 'Neoliberal, Balanced Budget' Social Structure of Accumulation? Emerging Prospects for the United States and World Economics,” in The Economic of Public Spending: Debts, Deficits and Economic Performance, edited by Hassan Bougrine. Cheltenham, UK and Northampton, US: Edward Elgar, 2000, pp. 30-56.

O’Hara, Phillip Anthony. "Recent Changes to the IMF, WTO and SPD: Emerging Global Mode of Regulation or Social Structure of Accumulation for Long Wave Upswing?” Review of International Political Economy 10 (2003): 485-518

O’Hara, Phillip Anthony. Growth and Development in the Global Political Economy: Social Structures of Accumulation and Modes of Regulation. London \& New York: Routledge, 2006a.

O’Hara, Phillip Anthony. “A New Neoliberal Social Structure of Accumulation for Sustainable Global Growth and Development?”, in Alternative Theories of the State, edited by Steven Pressman. London: Palgrave Macmillan, 2006b, pp. 91-112.

O’Hara, Phillip Anthony. “A Chinese Social Structure of Accumulation for Capitalist Long Wave Upswing?”, Review of Radical Political Economics 38 (2006c): 397-404.

O’Hara, Phillip Anthony. “The Global Securitized Subprime Crisis.” Review of Radical Political Economics 41 (2009): 318-334.

PC. (Australian Productivity Commission.) Aggregate Productivity: Highlights-Longer-Term Trends. Canberra: ACT, 2007.

Palley, Thomas. Financialization: What it is and Why it Matters. Annandale-on-Hudson, New York: Levy Economics Institute, 2007. Working Paper No 525, 2007.

Stanfield, James Ronald. "Review of Beyond the Wasteland: A Democratic Alternative to Economic Decline." Journal of Economic Issues 18 (1984): 1233-1238.

Stockhammer, Engelbert. "Financialisation and the Slowdown of Accumulation." Cambridge Journal of 
Economics 28 (2004): 719-741.

UNECE. (United Nations Economic Commission for Europe.) National Accounts: GDP Per Capita. Online Statistical Portal.

United States Department of Labor. Monthly Labor Review. Various Issues. Washington DC: USDOL, 20002001.

Wolfson, Martin. H. Financial Crises: Understanding the Postwar U.S. Experience. Armonk, New York: M.E. Sharpe, 1994.

World Bank. WDI Online: GDP Per Capita Growth (Constant Prices). Washington DC: World Bank, 2009. Online Subscription. 